\title{
Digital Transformation Drivers of Russian Business
}

\author{
Anastasia Levina \\ Peter the Great St.Petersburg \\ Polytechnic University; \\ Graduate School of Business and \\ Management
}

Saint Petersburg, Russia

alyovina@gmail.com

\author{
Sofia Kalyazina \\ Peter the Great St.Petersburg \\ Polytechnic University; \\ Graduate School of Business and \\ Management \\ Saint Petersburg, Russia \\ kaliazina.s@gmail.com \\ Alissa Dubgorn \\ Peter the Great St.Petersburg \\ Polytechnic University; \\ Graduate School of Business and \\ Management \\ Saint Petersburg, Russia \\ alissa.dubgorn@gmail.com
}

\author{
Victoria M. Iliashenko \\ Peter the Great St.Petersburg \\ Polytechnic University; \\ Graduate School of Business and \\ Management \\ Saint Petersburg, Russia \\ vmi1206@yandex.ru
}

\begin{abstract}
The paper is devoted to analyzing the company activities in the transition to digitalization, highlighting the main interests of key stakeholders in the digital transformation of the business, as well as the possibility of digital technologies to meet these needs. The result of the study is to create the basis for the formation of the principles of transition to a digital economy, as well as the principles of the functioning of Russian business in the context of digital transformation. During the study, the main drivers of the digital business transformation were formulated and presented as a motivational extension with a correlation with stakeholders in digitalization.
\end{abstract}

Keywords - digital transformation, drivers, Russian business, economic market, motivation development

\section{INTRODUCTION}

Digital transformation is associated with a significant increase in the amount of data that can be converted into information valuable for a particular business purpose. Digital technologies, which are the main driving force behind digital transformation, affect the business and enable consumers to provide unique value. The use of digital technologies provides organizational changes that can significantly improve the productivity (increase efficiency) of companies. Digital transformation is the process of integrating digital technologies into all aspects of business activity, requiring fundamental changes in technology, culture, operations and the principles of creating new products and services $[1,2]$.

Digital business in accordance with the program "Digital Economy of the Russian Federation" [3] is "... a key driver of production in all areas of socio-economic activity, which increases the country's competitiveness, the quality of life of citizens, and ensures economic growth ...". The creation of new principles for the functioning of the business environment, new digital business models and architectures is associated with fundamental reengineering and a review of existing restrictions on the activities of economic entities. The paper is aimed at identifying the key interests of the main participants of the national business environment and forming on this basis the requirements for the new digital economy $[4,5]$.

\section{LITERATURE REVIEW}

A study was conducted by analyzing information from open sources in order to determine the current level of digitalization in Russia, including in comparison with international experience.

The formation of the digital economy in the Russian Federation includes four main stages:

- Creating an infrastructure for access to digital technologies

- Using digital technology in everyday life

- Skills for the competent use of technology - "digital competencies"

- Effects of digitalization and the formation of a digital economy

According to a study by Thomas Mesenburg [6], three main components of the concept of a digital economy can be distinguished:

- Supporting infrastructure (hardware and software, telecommunications, networks, etc.);

- Electronic business (conducting business activities and any other business processes through computer networks);

- Electronic commerce (distribution of goods via the Internet).

Analysis of the level of digitalization of the economy in the countries of the European Union (EU) is estimated using the index of the digital economy and society (DESI). This is a composite index that summarizes the relevant indicators on the effectiveness of digital technologies and is calculated according to six main indicators: 
- Network communication. Shows the degree of deployment of broadband infrastructure in the country and its quality.

- Human resource: Shows the availability of digital skills in the staff.

- Use of Internet services by the public. Takes into account various online activities such as consumption of online content (video, music, games, etc.), video calls, online shopping, banking, etc.

- Integration of digital technologies in business. Measures the level of digitization of business and eCommerce in terms of the use of digital marketing technologies, online orders, online payments, etc.

- Digital public services. Allows you to evaluate the digitization of public services with a focus on the use of e-government services, in particular e - government and e-health.

- Research and development in information and communication technologies (ICT). Demonstrates an analysis of trends in the ICT and R \& D sector.

To date, all EU countries annually improve their digital performance. Finland, Sweden, the Netherlands and Denmark received the highest marks in DESI 2019 and are among the world leaders in digitalization. Evaluation and comparative analysis of the digitalization level of the EU countries in comparison with other countries is carried out using the International Index of Digital Economy and Society (I-DESI).

As the main factors affecting the creation of digital conditions for a rapidly changing business, the owners and top management of the companies distinguish the following:

1. The desire of companies to perfect experience is the reason for digitalization of $30 \%$ of enterprises

2. Change in the behavior of market players. The current factor forced about $18 \%$ of businesses to switch to the digital direction. Partners and competitors master new technologies, introduce innovative tools and platforms, change processes. In order to keep up with the leaders, each of the interested companies has to develop a digital segment.

3. Investments by market leaders in "disruptive technology" are the reason for the transition to digitalization of about $12 \%$ of companies - at first, this technology seems less profitable than the usual ones. However, over time, it completely displaces them and radically changes the market.

4. $10 \%$ of businesses decided to transform due to fierce competition in the segment. At some point, the market is narrowing, and the struggle for profits escalates to the limit. Market players have to change or leave the industry.

5. New opportunities in new markets are seen as the impetus for digitalization by the leaders of $6 \%$ of companies.

6. A sharp change in the market ecosystem and the rapid departure of individual players made $3 \%$ of entrepreneurs think about the digital future.
7. The struggle for valuable employees and the desire to remain an attractive employer forced $3 \%$ of companies to change $[7,8]$.

Within the framework of the "Digital Economy of the Russian Federation" program [9], the integrated "National Index of the Digital Economy Development" was developed - an information-analytical tool for monitoring and evaluating the development of the digital economy at the international, national, regional and industry levels, and its pilot was conducted calculation for 31 European countries and Turkey. As part of this work, composite sub-indexes were constructed and analyzed that characterize the main factors of digital transformation of the economy, the use of digital technologies in the public sector, business and citizens, as well as the social and economic effects of digital transformation. Russia ranks 23rd in the ranking for this index.

A special program "Industry Digitalization" has been launched in Russia to develop digital transformation projects and attract financing. This program also helps to identify the opportunities, benefits and economic benefits of digitalization and plan the transformation of business processes of industrial enterprises. Standardization is also important for the development of digital technology [10].

In Russia, studies were conducted on the prevalence of digital transformation, for example, "Digital Transformation in Russia 2018". According to the research, a number of basic trends that are characteristic of the digitalization process in Russia can be identified both in terms of the technologies used and the areas of digitalization [11].

The main technological trends are artificial intelligence, robotics, blockchain, unmanned vehicles and the Internet of things.

In the context of the development of these technologies, the development of cybersecurity is also reaching a fundamentally new level. The main industries leading in the use of digital technologies in Russia are the banking sector and the financial services sector, IT and software development, telecom, retail, insurance, digitalization of public services.

A significant criterion for the introduction of digital technologies is the need to ensure control over the production process. With the introduction of innovations, enterprises expect to improve the quality of products and reduce the number of rejects, increase labor productivity, as well as increase the export orientation of products.

Comparison of the data with the analysis of digitalization trends in the world as a whole shows that, on the whole, the trends coincide. In some areas in Russia there is some lag; in some areas, serious successes are demonstrated. In some cases, the expansion of the use of technology is hampered by the lack of a legislative framework, for example, in relation to unmanned vehicles, blockchain.

According to a study of digitalization trends in Russia, the healthcare sector is among the "beginners," while significant success has been achieved in the world in this area. It is advisable to develop the use of additive technologies, artificial intelligence, predictive diagnostics, and electronic cards in the field of medicine in Russia. An 
important digitalization trend in the energy segment is the Smart Grid concept. It is desirable to develop the concept of Smart City.

Thus, in Russia there are separate prerequisites and very high expectations in the field of digitalization of the economy. It is important to identify key stakeholders of Russian business and their driving forces for the development of digitalization with the goal of digital transformation of the entire economic system of the state, from macro to micro level.

\section{MethodOLOGY}

The methodological basis of this study was the approaches of business engineering and enterprise architecture, allowing to understand the internal structure of the business, emerging, including in response to requests and expectations of the external environment and stakeholders. [12] Within the framework of the enterprise architecture, all elements that make up the internal structure of business management are examined - from strategy, goals, business model, to business and technological processes, organizational structure, information systems, production equipment and it infrastructure $[13,14,15]$. We also use the concept of motivational expansion, which is understood as a model of external forces (stakeholders, drivers of the situation, constraints, requirements, assessments) that affect the emerging business architecture $[16,17]$. Simulation of motivational expansion is associated with the definition of driving forces and requirements of key stakeholders to the system. In this article, the model of motivational expansion is used for the processes of digital transformation of Russian business. [18]

\section{IV.MODELING MOTIVATIONAL DEVELOPMENT OF DIGITAL TRANSFORMATION}

To understand the main expectations and requirements of Russian business from the transition to the digital economy, it is important to identify the key stakeholders of Russian business and their interest (drivers) in digitalization. There were 4 main groups of stakeholders, each of which has its own special characteristics and special expectations from the use of digital:

- State - implies both the national economy as a whole, and the totality of state and municipal bodies, one way or another influencing or having an interest in the business environment and its subjects within the country in.

- The market as an institutional environment - the entire set of market entities, their relationships, internal regulatory mechanisms;

- Branches of the national economy - various subject areas of the economy that have their own specific objects of activity and technology for the implementation of this activity;

- Legal entities and private entrepreneurs - the main subjects of the business environment, carrying out their business activities in this state.

The main interest of the state in the sphere of economy is the possibility of stable growth of the national economy. From the point of view of possibilities of digital technologies it is necessary to ensure transparency of activities is accountable to the state and municipal authorities of constituent entities of the business environment, as well as the effectiveness of communication of public authorities and business and the available urban infrastructure.

The market as an environment for doing business is primarily interested in the overall improvement of the quality of services and products, as well as in the competitiveness of national products and services in the global market [19]. Digital technologies in this direction can help to improve the efficiency of communications of market entities, as well as to guarantee the reliability of agreements of entities, including in the global market (in particular, using the regulatory mechanism of electronic contracts with the use of blockchain technology).The market as an environment for doing business is primarily interested in the overall improvement of the quality of services and products, as well as in the competitiveness of national products and services in the global market. Digital technologies in this direction can help to improve the efficiency of communications of market entities, as well as to guarantee the reliability of agreements of entities, including in the global market (in particular, using the regulatory mechanism of electronic contracts with the use of blockchain technology).

It is important for individual business entities (legal entities and individual entrepreneurs) to be able to reach a wider audience of consumers, improve the quality of information exchange within the entity, and optimize processes according to various criteria. The ability to create a wide range of clients allows interested individuals to reach a high level of income and establish themselves in a high position.

An important component of an effective system of national business is the availability of a single information space available to all participants of the business environment. The presence of such information space will provide all participants with consistent, uniform, up-to-date information, which will ensure both the effectiveness of communications in the system and create prerequisites for creating a competitive environment.

The listed stakeholders and their key interests are presented in the model of motivational expansion of digital transformation in Figure 1. As part of creating a motivational expansion, certain drivers were identified that correlated with their stakeholders.

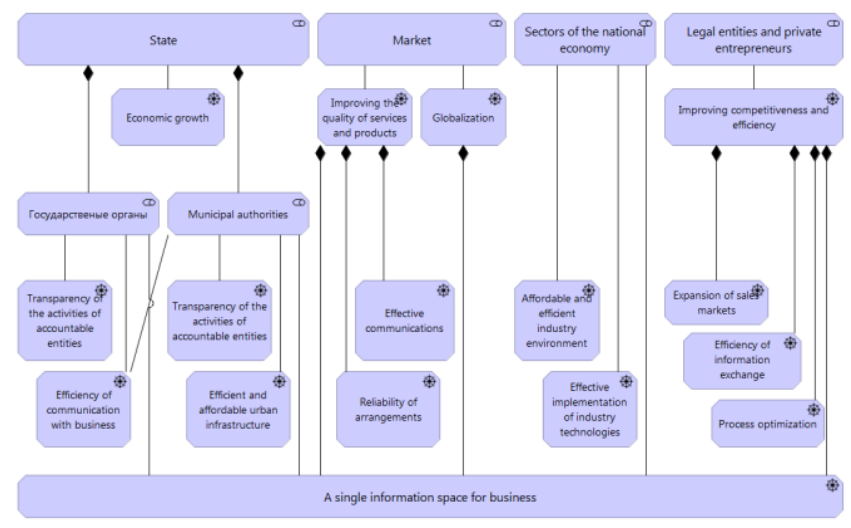

Fig.1. Model of motivational development of the Russian business system in the transition to digital economic. 
To meet the listed in the model in Fig. 1 business needs the following digital technologies can be used in the transition to a digital economy:

- electronic platforms;

- Internet of things;

- big data, predictive analytics;

- blockchain;

- cyber-physical systems;

- machine-to-machine interaction.

The main tools for planning production processes include such tools as digital modeling and optimization of business processes, analysis of human resources, operational and financial planning systems. Key production management tools are CAD (Computer Aided Design), CAM (ComputerAided Manufacturing), CAE (Computer-aided engineering), APS (Advanced Planning \& Scheduling), EAM (Enterprise Asset Management), CPM (Corporate Performance Management) systems [20].

The qualitative effect of the use of the tools and technologies discussed is the optimization of the company's work, improving the accuracy of meeting deadlines, increasing labor productivity, improving product quality, accelerating the launch of the product on the market, the possibility of obtaining new product properties, and expanding the sales market. As a quantitative effect, one can note a reduction in losses and production costs, an increase in the efficiency of using production capacities, and an increase in the number of completed orders. In general, this ensures profit growth due to lower cost and higher sales, increased competitiveness by reducing the time required to complete the work.

\section{CONCLUSION}

This article identifies the main interests of key stakeholders in the digital transformation of business, as well as the possibility of digital technologies to meet these needs. The results of the analysis form the basis for the formation of the principles of transition to the digital economy, as well as the principles of functioning of Russian business in the conditions of digital transformation. Companies should be ready for organizational changes, have a clear strategy of digital transformation, understand the target business model and conduct appropriate reengineering of business processes in order for digitalization projects to bring their core value increased profitability and business efficiency.

\section{ACKNOWLEDGMENT}

The reported study was funded by RSCF according to the research project № 19-18-00452.

\section{REFERENCES}

[1] What is digital transformation? [Electronic source]: https://www.hpe.com/ru/ru/what-is/digital-transformation.html (application date: 10.08.2019)

[2] Ismagilova, L.A., Gileva, T.A., Galimova, M.P., Glukhov, V.V. Digita business model and smart economy sectoral development trajectories substantiation (2017) 10531 LNCS, pp. 13-28

[3] National program "Digital Economy of the Russian Federation». Approved: 24.12.2018. [Electronic source] // URL: http://government.ru/rugovclassifier/614/events/ (application date: 08.08.2019).

[4] Kapranova L.D. The digital Economy in Russia: its State and Prospects of development // Economics and Management DOI: 10.26794/1999-849X-2018-11-2-58-69, №2 (2018).

[5] Borremans, A.D., Zaychenko, I.M., Iliashenko, O.Yu. Digital economy. IT strategy of the company development (2018) 170, 01034.

[6] Mesenbourg, T. L. (2001). Measuring the digital economy. US Bureau of the Census.

[7] The development of the digital economy in the European Union [Electronic source] https://www.ictsd.org/bridges-news/news/ development-digital-economy-in-european-union (application date: 08.08.2019)

[8] Digital transformation: main reasons [Electronic source]/https://l-a-ba.com/blog/show/499?utm_source=google (application date: 08.08.2019)

[9] State Corporation Rosatom. National Digital Economy Development Index.Госкорпорация Росатом. [Electronic source] // URL: http://digitalrosatom.ru/wp-content/uploads/2019/01.pdf (application date: 08.08.2019)

[10] Bataev, A.V. Analysis and development the digital economy in the world (2018) pp. 61-71.

[11] Digital transformation in Russia, 2018. Analytical report. [Electronic source] // URL: https://komanda-a.pro/blog/dtr_2018 (application date: 08.08.2019)

[12] Ilin, I., Grigoreva, A. How stakeholders make decision about changes in enterprise architecture. Cases in private business and public organization (2017) 2018, pp. 50-62.

[13] The Open Group. TOGAF Version 9.2, 2018. Electronic source] // URL: http://pubs.opengroup.org/architecture/togaf92-doc/arch/ (application date: 15.08.2019).

[14] Lankhorst M. Enterprise Architecture at Work. Modelling, Communication, Analysis // Springer-Verlag, 2013. - 338 c.

[15] Ilin, I., Levina, A., Iliashenko, O. Enterprise Architecture Analysis for Energy Efficiency of Saint-Petersburg Underground (2018) 692, pp. 1214-1223.

[16] Levina, A.I., Borremans, A.D., Burmistrov, A.N. Features of enterprise architecture designing of infrastructure-intensive companies (2018) Proceedings of the 31st International Business Information Management Association Conference, IBIMA 2018: Innovation Management and Education Excellence through Vision 2020, pp. 4643-4651.

[17] Op’t Land M., Proper E., Waage M., Cloo J., Steghuis C. Enterprise Architecture. Creating Value by Informed Governance // Springer Verlag, Берлин, 2009. -154 p.

[18] CIO Council. Federal Enterprise Architecture Framework Version 1.1. September 1999. [Electronic source] // URL: http://www.enterprisearchitecture.info/Images/Documents/Federal\%20EA\%20Framework. pdf (applicaion date: 15.08.2019).

[19] Weforum. URL: http://reports.weforum.org/global-competitivenessreport-2014-2015/methodology/ (applicaion date: 15.08.2019)

[20] Robert Green. Expert CAD Management: The Complete Guide, 2016 $-291 \mathrm{p}$. 